\title{
Prescription opioids and new business establishments
}

\author{
Cornelius A. Rietveld • Pankaj C. Patel
}

Accepted: 11 March 2020 / Published online: 14 April 2020

(C) The Author(s) 2020

\begin{abstract}
The effects of opioid abuse on health are widely documented, however, its effects on labor market outcomes have only recently become a topic of scientific inquiry. Whereas recent economic studies focus on various measures of labor market participation, the present study analyzes whether opioid prescription rates are associated with the impetus for entrepreneurial activity. By drawing on samples of US counties and US neighbor county-pairs across state borders from the years 2007 to 2016, we find that higher opioid prescription rates are associated with fewer non-employer establishments and new firms employing 1-4 employees. In an ancillary analysis of 50 US states from the years 2006 to 2016, we further show that opioid prescription rates are associated with lower entrepreneurial activity in general and opportunity-based entrepreneurial activity in particular. Overall, both the county-level and state-level analyses show that a higher rate of opioid prescriptions is negatively associated with new business formation. Although the estimated effect sizes are small, they are sizeable in absolute terms.
\end{abstract}

Keywords New business formation · Entrepreneurship · Opioids

\section{A. Rietveld $(\bowtie)$}

Erasmus School of Economics, Erasmus University Rotterdam, Burgemeester Oudlaan 50, 3062 PA Rotterdam, The Netherlands e-mail: nrietveld@ese.eur.nl

P. C. Patel $(\bowtie)$

Villanova School of Business, Villanova University, 800 E.

Lancaster Avenue, Villanova, PA 19085, USA

e-mail: pankaj.patel@ villanova.edu
JEL codes $\mathrm{J} 01 \cdot \mathrm{L} 26 \cdot \mathrm{M} 13$

\section{Introduction}

Opioids produce morphine-like effects and are used for various medical reasons such as suppression of pain, diarrhea, and cough. Still, opioids are also often used for non-medical reasons because of their amplifying effects on euphoria and intense feelings of happiness. Opioids are addictive, and escalating recreational use of opioids may result in addiction. Rates of opioid misuse are estimated to be between 21 and $29 \%$ and rates of addiction between 8 and $12 \%$ (Vowles et al. 2015). Strikingly, every day, more than 130 people die after overdosing on opioids in the USA (National Institute on Drug Abuse 2018). The effects of opioid abuse are so farreaching in the USA that the Department of Health and Human Services declared the opioid crisis in 2017 a national emergency.

In addition to the widely studied effects on health and the social costs of prescription opioid abuse (Reinhart et al. 2018), a recent stream of literature has started to investigate the effect of prescription opioids on labor market outcomes. Based on county-level data, Harris et al. (2019) find strong adverse effects on labor force participation rates, employment-to-population ratios, and unemployment rates. Currie et al. (2019) find that the effect of opioids on employment-to-population ratios is positive but small for females and absent for males. When 
analyzing the relationship in the opposite direction, they find that there is no clear relationship between economic conditions and the abuse of opioids. The findings of Aliprantis et al. (2019) are largely in line with these results: Increases in the local opioid prescription rate decrease prime-age employment rates for both males and females; however, short-term unemployment shocks were not associated with the share of people abusing prescription opioids.

Building on and extending this focused, but growing, stream of research on the economic impact of the opioid crisis, we analyze the association between opioid prescriptions and new entrepreneurial activity on both county and state levels. The use of aggregated data has a particular advantage over using individual-level data (Harris et al., 2019): Self-reports of opioid use are subject to reporting bias and measurement error, and it is known that a considerable share of prescribed opioids is not consumed by the one it is prescribed to but by family, friends, or others. An individual-level analysis is less likely to capture these dynamics, but countyor state-level analysis allows estimation of the overall association between per capita opioid prescriptions and new business establishment. Cascades and spillovers from opioid abuse through social and economic strata are better captured at an aggregated level. Therefore, in this study, we use the aggregate county- or state-level opioid prescription rates as compiled by the Center for Disease Control. From a policy perspective, the use of county-level data comes with the advantage that policies aimed at tackling the problems associated with opioid abuse and campaigns for promoting firm startups are often developed at the county level. At the county level, there is substantial variation in opioid abuse (Schuchat et al. 2017). Hence, our findings can be informative for county-level policies.

Our results show that at the county-level (in the full sample of counties as well as in the subsample of neighbor counties across state borders), higher opioid prescription rates are associated with fewer non-employer establishments and new firms employing 1-4 employees. At the state level, we find that opioid prescription rates are associated with lower entrepreneurial activity in general and opportunity-based entrepreneurial activity in particular. The effect sizes at the county-level and statelevel are small, but sizable in terms of absolute numbers. Though we stress that these results should be interpreted as associational relationships rather than causal relationships, these findings are informative about the relationship between opioid prescriptions and economic development and supplement the finding by Harris et al. (2019) that prescription opioids have a negative effect on the labor force participation rate. Our results show that decreased levels of new business activity may be another channel through which prescription opioids may be negatively associated with a county's composition of the labor force and structure of the economy.

The remainder of this study is organized as follows. The following section elaborates on the literature background of this study and formulates expectations about the relation between the opioid prescription rate and new business formation at county and state levels. Section 3 describes the data we draw on as well as the methodology we adopt to analyze the data. Section 4 presents the empirical results. The final section discusses the findings and concludes with policy recommendations and directions for future research.

\section{Literature background}

The opioid crisis in the USA has reached "epidemic levels" (White House Council of Economic Advisors 2017). According to the Center for Disease Control, between 1990 and 2017, 400,000 people died of opioid abuse and with no sign of abating, opioid overdoses increased by $30 \%$ between July 2016 and September 2017 in 52 areas in 45 states (Center for Disease Control 2017). Opioid abuse has a detrimental effect on individuals, families, and local communities (Birnbaum et al. 2011; Meyer et al. 2014). Though opioid abuse is mainly driven by demand from patients, a recent set of studies focuses on the role of supply-side drivers of opioid prescriptions. For example, Barnett et al. (2017) show that long-term opioid use was greater among patients treated by high-intensity opioid prescribers. Relatedly, Schnell and Currie (2018) find that physicians from top-ranked medical schools write fewer opioid prescriptions. Strikingly, considering that patients may turn to the secondary (black) market to procure opioids, physicians overprescribe by at least 
$20 \%$ (Schnell 2017). To ameliorate the opioid crisis, US states have passed prescription drug monitoring programs (PDMPs). By electronically monitoring the prescription of drugs, PDMPs can help to identify individuals who may be misusing prescription opioids or other prescription drugs. However, Buchmueller and Carey (2018) found that such programs have no effect on opioid prescriptions without must access provisions, i.e., the obligation to query the PDMP prior to prescribing opioids. ${ }^{1}$

The role of public health in driving economic activity is documented in studies highlighting public health conditions as important predictors of future growth (Knowles and Owen 1997). The notion that investments in human capital-including health (Becker 1964)-improves economic outcomes has received broad support since the 1960s (Grossman 1972; Leibowitz 2004; Bloom et al. 2004). In both developed (Aghion et al. 2010; Swift 2011) and developing (Bhargava et al. 2001) economies, health is associated with economic growth. Good health is also considered to be of crucial importance for new business formation, because of demanding working hours and increased capacity to cope with stressors coming with running a business (Rietveld et al. 2015; Buttner 1992). Therefore, our core theoretical premise on the relationship between opioid abuse and firm formation stems from the health capital literature. Still, we caution that our research topic is relatively new and there may be other relevant mechanisms explaining the complex and dynamic relationship between opioid abuse and new business formation.

Our expectations about the relationship between the opioid prescription rate and new business activity are based on the notion that opioid abuse deteriorates both individual health capital and, therefore, the aggregate human capital stock in an area (Howitt 2005). Poorer health lowers an individual's productive efficiency (Cai and Kalb 2006) through increased absenteeism, lower attention to tasks, lower physical energy, poorer mental attention, and reduced creativity. Moreover, poor health lowers life

\footnotetext{
${ }^{1}$ To fight the opioid epidemic, states also passed naloxone access laws over time. Doleac and Mukherjee (2018) show that access to naloxone increases opioid-induced emergency room visits and opioid-related theft. They could not find a meaningful influence on opioid-related mortality, but Packham (2019) finds such an effect especially in rural and high-poverty areas.
}

expectancy and the overall stock of human capital. Opioid abuse deteriorates an individual's health capital and therefore also the aggregate human capital stock in a region. The presence and size of a creative class are important factors explaining differences in regional entrepreneurial activity (Florida 1995), and a deteriorated level of structural, cognitive, and affective human capital may, therefore, impact the entrepreneurial capacity of a region. In addition, the opioid crisis weakens the social cohesion of the local community through higher divorce rates, orphaned children, bankruptcy, poverty, and a broader sense of distress and hopelessness (Florence et al. 2016; Dasgupta et al. 2018). The weakened social and communal cohesion would not only lower the overall stock of human and financial resources in a region but also reduce the bonding, bridging, and linking capital in communities.

The few studies analyzing the relationship between opioid prescription rates and employment rates all highlight the adverse effects on labor force participation rates and unemployment rates. The studies by Harris et al. (2019), Currie et al. (2019), and Aliprantis et al. (2019) also highlight that this relationship may differ depending on the use or misuse of opioids. That is, the therapeutic potential of opioids may enhance labor force participation but the illegitimate uses may adversely affect it by making it harder to perform at an adequate level in wage work. Several studies have shown that good health is an important asset for the setup and survival of a business (Rietveld et al. 2015; Hessels et al. 2018), and hence, the therapeutic use of opioids may positively influence the ability to create jobs by starting or expanding a business. Harris et al. (2019) present evidence that opioid abuse impels exit from the labor force entirely because the relationship between the opioid prescription rates with the unemployment rate is marginally small, whereas the relationship with the labor force participation rate is significantly negative.

Increases in the local opioid prescription rate decrease prime-age employment rates for both males and females (Aliprantis et al. 2019), primarily by making people leave the labor force entirely (Harris et al. 2019). The likelihood of business start-up is highest for individuals in this age category (Levesque and Minniti 2006), because of their levels of human capital and occupational experience. Hence, despite enhanced feelings of euphoria and 
possibly self-efficacy through opioid use, overall (i.e., the net effect), it is most likely that rates of new business creation will be lower in regions with higher opioid prescription rates. Innovative replacement of old techniques and products with new ones by businesses is considered to be a key factor contributing to economic growth. Innovation revolutionizes industries from within and brings industries and the economy as a whole to a higher level. Therefore, we also expect the level of competition within industries to go down in case fewer new businesses enter the market.

\section{Data and methodology}

\subsection{Sample}

Our primary empirical analysis draws on county-level data from the USA, and our secondary empirical analysis is based on state-level data from the USA. In the countylevel data, we distinguish between the full sample and neighbor county-pairs on opposite sides of a state border within the sample. The county-pairs are based on the closest geographic distance between centroids of the two neighboring counties across a state border. Dube et al. (2010) have shown that estimates in the latter subsample are more precise because neighboring counties are relatively similar in terms of geography and economic activity, and hence, the presence of the state border between these neighboring counties may facilitate the estimation of effects of state-level laws (see Sect. 3.4). After casewise deletion, we draw on 2711 counties (22,057 county-year observations from 2007 to 2016) in the full sample and 1011 counties (7964 county-pair-year observations from 2007 to 2016) in the neighbor countypair sample. For the state-level analysis, we use data from all the 50 US states (547 state-year observations from 2007 to 2017). All data sources are mentioned in Sect. 3.2 (county-level analysis) and Sect. 3.3 (state-level analysis), and more detailed descriptions are available in Tables 6 , 7 , and 8 in the Appendix.

\subsection{Primary analysis: county-level analysis}

\subsubsection{Outcome variables}

The Small Business Administration defines a small and medium enterprise as a firm with 500 or fewer employees. In our study, we focus on the smallest and most prevalent type of (new) establishments: (i) the logarithm of the number of non-employer establishments from the U.S. Census Bureau; and (ii) the logarithm of the number of new establishments with 1-4, 5-9, 10-19, and 20-49 employees from County Business Patterns. A majority of firms in the USA are non-employer firms (Miranda and Zolas 2017). These firms do not hire any employees and include a variety of entrepreneurs including solo entrepreneurs, contractors, husband-wife teams, and professional services firms. New firm establishments (e.g., 1-4 employees) with relatively few employees also represent a distinct firm type and cover new firms that are typically entrepreneurial and less likely to be a byproduct of spinoffs or company establishments (Acs and Armington 2006).

\subsubsection{Predictor variable}

Our main explanatory variable is the number of retail opioid prescriptions per 100 residents in a county (lagged by 1 year), as provided by the Center for Disease Control.

\subsubsection{Control variables}

Besides the inclusion of year fixed effects in our models, we use three sets of control variables. The first set includes characteristics of the county itself. Recent research shows that the regional poverty level and racial composition may be associated with the prescription opioid epidemic (Song 2017). Therefore, we control for the logarithm of the median real household income in the county, the percentage of whites in the county population, and the poverty rate in the county. The median household income and poverty rates were obtained from the U.S. Census Bureau's Small Area Income and Poverty Estimates. The percentage white population in the county was obtained from the U.S. Census Bureau's American Community Survey estimates. Moreover, crime (especially drug-related crime) may be associated with ease of access to opioid prescriptions in the secondary (black) market. Therefore, we control for the logarithm of violent crime in the county and the logarithm of property crime in the county. To directly control for the association between the opioid prescription rate and drug-related crimes, we also control for the logarithm of total drug-related offenses in the county. County-level crime-related data were 
obtained from the Federal Bureau of Investigation's Uniform Crime Reporting Program Data at the countylevel.

Motivated by the local identification strategy used by Dube et al. (2010), we include variables regarding the characteristics of the border county in the second set of control variables. This set of control variables is only used in the neighbor county-pair analysis. Specifically, we control for the neighbor county opioid prescription rate and the logarithm of the median real household income in the neighboring county.

Our third set of controls captures the state-level opioid prescription laws which are likely to influence the county-level opioid prescription rate. We control for whether the county belongs to a state with must access laws from the Prescription Drug Abuse Policy System (PDAPS) with two binary variables. The first binary variable reflects whether the state of the county has any Prescription Drug Monitoring Program (PDMP) law $(1=$ Yes; $0=$ No). The second binary variable indicates whether the state has a must access law meaning that the state requires prescribers and dispensers to check the PDMP before prescribing controlled substances $(1=$ Yes; $0=$ No; Table 7 in the Appendix shows the presence of must access laws by state). In the neighbor county-pair analysis, we also control for whether the state of the neighbor county has any PDMP law (1= Yes; $0=$ No), and whether the neighbor county has a must access law $(1=$ Yes; $0=$ No).

\subsection{Secondary analysis: state-level analysis}

As a secondary analysis, we analyze new entrepreneurial activity at the state level. Our argumentation that higher opioid prescription rates are associated with a lower number of new firm establishments holds for the aggregated county level as well as other levels of aggregation such as the state. Statelevel data is less fine-grained than county-level data, and the sample size for the state-level analyses is relatively small because there are fewer states than counties in the USA. Nevertheless, analyses at state level may be informative about the robustness of the county-level results.

\subsubsection{Outcome variables}

We analyze two state-level entrepreneurship outcomes which are provided by the Kauffman Foundation
(Fairlie 2013; Kauffman Foundation 2018). The first measure, the Kauffman Index of Entrepreneurial Activity (KIEA), is a Z-score of (i) the rate of new entrepreneurs among the US adult population; (ii) the opportunity share of new entrepreneurs, or the percentage of new entrepreneurs primarily driven by "opportunity" vs. by "necessity"; and (iii) the start-up density (new employer businesses less than one-year-old, normalized by the population).

\subsubsection{Predictor variable}

Our main explanatory variable, similar to the countylevel analysis, is the number of retail opioid prescriptions per 100 individuals in a state (lagged by one year), as provided by the Center for Disease Control.

\subsubsection{Control variables}

Because opioid prescription rates could be associated with low-income states, we include the logarithm of the gross state product (measured in millions of current dollars, all industry total), the logarithm of state personal income (measured in thousands of current dollars), and the poverty rate (percentage). Cannabis-related laws and support for the poor may be associated with the political atmosphere in a state, and therefore, we control for whether the governor is a democrat $(1=\mathrm{Yes} ; 0=\mathrm{No})$ because the governor has the ultimate veto power on state laws. To control for individuals on government transfer payments, we control for the state Earned Income Tax Credit (EITC) rate (as percentage of the federal credit), the state minimum wage in dollars per hour, the logarithm of Aid to Families with Dependent Children (AFDC), and Temporary Assistance for Needy Families (TANF) caseloads (average monthly number of total family caseloads for AFDC and TANF). The demographic makeup of the state could also influence firm establishment; therefore, we control for the logarithm of population size and the logarithm of a number of employed state residents. These control variables are supplied by the University of Kentucky Center for Poverty Research (1980-2017) (University of Kentucky Center for Poverty Research 2017). In a final model, we also include a control variable capturing the presence of recreational marijuana law (cannabis is legal for recreational use or not, $1=$ Yes; $0=$ No). During 2010 and 2017, 32 states implemented medical cannabis laws, of which 17 states allowed only medical cannabis with 
low levels of the psychoactive tetrahydrocannabinol (THC) and high levels of the non-psychoactive component cannabidiol and eight states allowing the use of cannabis for recreational purposes (Shover et al. 2019). In all models, we include year fixed effects.

\subsection{Methodology}

We use fixed-effects specifications in which we investigate the relationship between the opioid prescription rate and new business establishment for both our primary (county-level) and secondary (state-level) analyses. In the primary analysis, the fixed-effects are included for each county. In the secondary analysis, they are included for each state. To lower concerns about reverse causality, we use the 1 year lag of the opioid prescription rates to analyze the relationship with new business formation. For the county-level analysis, we provide estimates for the full sample and the subsample of neighbor counties across border states. Dube et al. (2010) have shown that fixed-effects estimates that rely on cross-county variation may be prone to bias because of the large heterogeneity across counties (Dube et al. 2010). A neighbor county-pair analysis helps to reduce bias due to aggregated spatial heterogeneity in a sample (Dube et al. 2010), because "the geographic determinants of the distribution of [activity] are approximately the same on both sides of the border [and] if the policies make no difference, there should be no abrupt change at the border" (Holmes 1998, p. 671). Therefore, a neighborcounty across state border estimation approach that controls for PDMP and must access laws improves precision and lowers bias related to spatial heterogeneity.

Our control variables for the implementation of opioid laws in states and counties help to reduce bias from localized opioid trends. At the same time, the difference in implementation timing of these laws across states and counties makes a difference-in-difference design less applicable as identification strategy because of the varying pre-trends and varying intensities of treatments from the same unit (i.e., state) (see Appendix Table 7 for information about the passage of PDMP and must access laws in US states). Still, even with the border county-pair design, we are not able to draw causal inferences. Even with the border county-pair design, it is possible that individuals from stricter opioid prescription counties would simply travel to less strict counties across state borders. Though this is possible, individuals generally fill prescriptions from the same pharmacy, doctors must be licensed to practice in the state where they prescribe, and it is likely that the opioid crisis makes pharmacists careful in filling prescriptions from people from other counties or states. Nevertheless, opportunism in the prescription filling cannot be ruled out. To lower bias due to spillovers from traveling to another county, we control for neighbor county opioid prescription rates and neighbor county real household median income, in addition to the opioid laws in the neighbor county.

\section{Results}

\subsection{Descriptive statistics}

Table 1a (full sample) and Table 1b (county-pair subsample) depict the descriptive statistics of the county-level analysis sample. Importantly, in both the full sample and the county-pair subsample, there is considerable variation across counties in new business formation as well as in the lagged county opioid prescription rate. Table 1a indicates that in the full sample, $88.2 \%$ of the counties have some PDMP law at the state level and $8.8 \%$ have must access laws. These percentages are similar in the neighbor county subsample. Table 2 provides descriptive statistics for the sample included in the state-level analysis. Also, at the state-level, there is variation in terms of new business activity and the opioid prescriptions rate. Only in $2 \%$ of the stateyear observations between 2006 and 2016, there were laws for recreational marijuana use because most of the recreational marijuana laws were only passed recently. In the Appendix, we also provide scatter plots to showcase the raw relationships between the lagged opioid prescription rate and the outcome variables for the full county sample (Fig. 1), neighbor county sample (Fig. 2), and state sample (Fig. 3). These scatter plots do not indicate a systematic directional pattern between the lagged opioid prescription rate and the number of new firm establishments.

\subsection{Multivariate results}

The simple univariate analysis in the scatter plots is less informative due to the heterogeneity among counties and variations across years, and therefore, 
Table 1 Descriptive statistics county-level analysis and state-level analysis

Table 1 Descriptive statistics county-level analysis and state-level analysis

(a) Full county sample $\left(N_{\text {county-year }}=22,057, N_{\text {county }}=2711\right)$

\section{Outcome variables}

Logarithm of number of non-employer establishments

Logarithm of number of establishments with 1 to 4 employees

Logarithm of number of establishments with 5 to 9 employees

Logarithm of number of establishments with 10 to 19 employees

Logarithm of number of establishments with 20 to 49 employees

Main explanatory variable

Lagged county opioid prescription rate per 100 individuals (divided by 1000)

Mean

S.D.

Min.

Max.

Control variables

Any PDMP law in the state

Must access law in the state

Logarithm of real household income in the county

Percentage white population in county

Poverty rate in the county

Logarithm of violent crime rate in the county

Logarithm of property crime rate in the county

Logarithm of total drug-related offenses in the county

$\begin{array}{llll}9.338 & 1.330 & 5.624 & 15.399 \\ 6.155 & 1.295 & 2.773 & 12.001 \\ 5.152 & 1.319 & 1.386 & 10.660 \\ 4.662 & 1.400 & 0.000 & 10.294 \\ 4.108 & 1.527 & 0.000 & 9.968 \\ & & & \\ 0.088 & 0.045 & 0.000 & 0.437 \\ & & & \\ 0.882 & 0.322 & 0.000 & 1.000 \\ 0.088 & 0.283 & 0.000 & 1.000 \\ 10.806 & 0.238 & 10.048 & 11.855 \\ 78.444 & 18.966 & 0.95 & 99.96 \\ 11.922 & 5.466 & 0.49 & 41.75 \\ 5.238 & 0.863 & 0.530 & 7.686 \\ 7.484 & 0.708 & 1.338 & 9.501 \\ 4.903 & 1.652 & 0.000 & 11.299\end{array}$

(b) Neighbor county sample ( $\left.N_{\text {county-year }}=7964, N_{\text {county }}=1011\right)$

Outcome variables

Logarithm of number of non-employer establishments

Logarithm of number of establishments with 1 to 4 employees

Logarithm of number of establishments with 5 to 9 employees

Logarithm of number of establishments with 10 to 19 employees

Logarithm of number of establishments with 20 to 49 employees

Main explanatory variable

Lagged county opioid prescription rate per 100 individuals (divided by 1000)

9.370

1.363

5.768

14.541

6.207

1.330

2.944

11.218

5.204

1.342

1.386

10.017

4.710

1.430

0.000

9.674

4.152

1.554

0.000

9.343

0.092

0.047

0.001

0.437

Control variables

Any PDMP law in the state

0.870

0.336

0.000

1.000

Must access law in the state

0.100

0.301

0.000

1.000

Logarithm of real household income in the county

10.806

0.250

10.081

11.855

Percentage white population in county

79.983

17.665

9.890

99.07

Poverty rate in the county

11.879

5.476

0.490

39.05

Logarithm of violent crime rate in the county

5.234

0.869

1.223

7.686

7.465

0.720

1.338

9.198

Logarithm of total drug-related offenses in the county

4.960

1.671

0.000

10.897

Neighbor county opioid prescription rate

91.297

47.311

0.000

437.2

Neighbor county has any PDMP law

0.888

0.316

0.000

1.000

Neighbor county in a state with must access law

0.094

0.291

0.000

1.000

Neighbor county logarithm of real median household income

10.801

0.251

10.081

11.705

(c) State sample $\left(N_{\text {state-year }}=547, N_{\text {state }}=50\right)$

Outcome variables

Entrepreneurial activity index

$-0.431$

1.145

$-3.236$

2.880

Opportunity-based entrepreneurship

0.79

0.063

0.557

0.945 
Table 1 (continued)

\begin{tabular}{|c|c|c|c|c|}
\hline & Mean & S.D. & Min. & Max. \\
\hline \multicolumn{5}{|l|}{ Main explanatory variable } \\
\hline Lagged state opioid prescription rate per 100 individuals (divided by 1000) & 0.082 & 0.022 & 0.042 & 0.147 \\
\hline \multicolumn{5}{|l|}{ Control variables } \\
\hline Recreational marijuana law & 0.034 & 0.178 & 0.000 & 1.000 \\
\hline Logarithm of gross state product & 12.169 & 1.024 & 10.119 & 14.846 \\
\hline Logarithm of state personal income & 18.925 & 1.028 & 16.982 & 21.584 \\
\hline Poverty rate & 13.222 & 3.340 & 5.800 & 23.100 \\
\hline Governor is democrat & 0.441 & 0.497 & 0.000 & 1.000 \\
\hline State EITC rate & 0.072 & 0.111 & 0.000 & 0.850 \\
\hline State minimum wage & 7.399 & 0.993 & 2.650 & 11.000 \\
\hline Logarithm of AFDC and TANF caseloads & 9.561 & 1.240 & 5.587 & 13.343 \\
\hline Logarithm of population size & 15.175 & 1.007 & 13.190 & 17.493 \\
\hline Logarithm of number employed state residents & 14.418 & 0.987 & 12.537 & 16.727 \\
\hline
\end{tabular}

S.D. standard deviation, Min. minimum, Max. maximum

we continue by presenting the results of our multivariate analysis. Our fixed-effects specification for the full county sample is as follows:

$Y_{c t}=\alpha_{0}+\alpha_{1} O_{c t-1}+\alpha_{x} X_{c t}+\alpha_{c}+e_{c t}$,

with $Y_{c t}$ representing the logarithm of new firm establishment types by employee size in county $c$ in year $t, O_{c t-1}$ the lagged opioid prescription rate in county $c$ in year $t, X_{c, t}$ the set of control variables (including year dummies), $\alpha_{c}$ a vector with county fixed-effects, and $e_{c, t}$ the error term. For the full county-level analysis, we provide fixed-effects estimates in Table 2 for models with an expanding set of explanatory variables. In model 1 , the relationship between the lagged opioid description rate and each outcome is significantly negative (except for firm 5-9 and 10-19). The coefficient of our main variables is only marginally sensitive towards the inclusion of county-level control variables (model 2 ) as well as control variables capturing the presence of opioid laws (model 3).

In model 3, an increase of 10 opioid prescriptions per 100 residents (the original unit is per 100 individuals, but we divided values by 1000 for representation purposes) is associated with a $0.185 \%$ reduction in the number of non-employer establishments. This figure translates to 21.02 fewer new non-employee establishments in an average county. A similar increase in the opioid prescription rate is associated with a decline of
$0.135 \%$ in the number of new firms with 1 to 4 employees. Given the number of new businesses in this size class, this percentage translates into 0.64 fewer businesses in an average county. Interestingly, we find a positive association for size class 10-19. Here, the increase of 10 opioid prescriptions per 100 people in a county is associated with a $0.105 \%$ increase in the number of new business with this size ( 0.11 new businesses). For firm sizes between 20 and 49, we find a decline of $0.239 \%$ ( 0.15 businesses). We broadly conclude that business formation declines with higher opioid prescription rates. Effect sizes are small but relatively sizeable in absolute terms for non-employer establishments and new establishments with 1-4 employees.

Identification in the subsample of neighbor countypairs across state borders rests on the idea that the geographic determinants of the new business activity will be approximately the same on both sides of the border if policies make no difference. Therefore, we first compare whether neighbor counties are significantly different in terms of the control variables and in terms of gross domestic product (GDP). Some counties have multiple neighbors in common, and therefore, we focus on symmetrical neighbor counties in this analysis. That is, a county pair for which the first county is the neighbor of the second and vice versa. We randomly assigned one county in each county pair to be the focal county and the other to be the neighbor county in the analysis of differences. Moreover, we focus for these analyses on the observations included in the neighbor county 


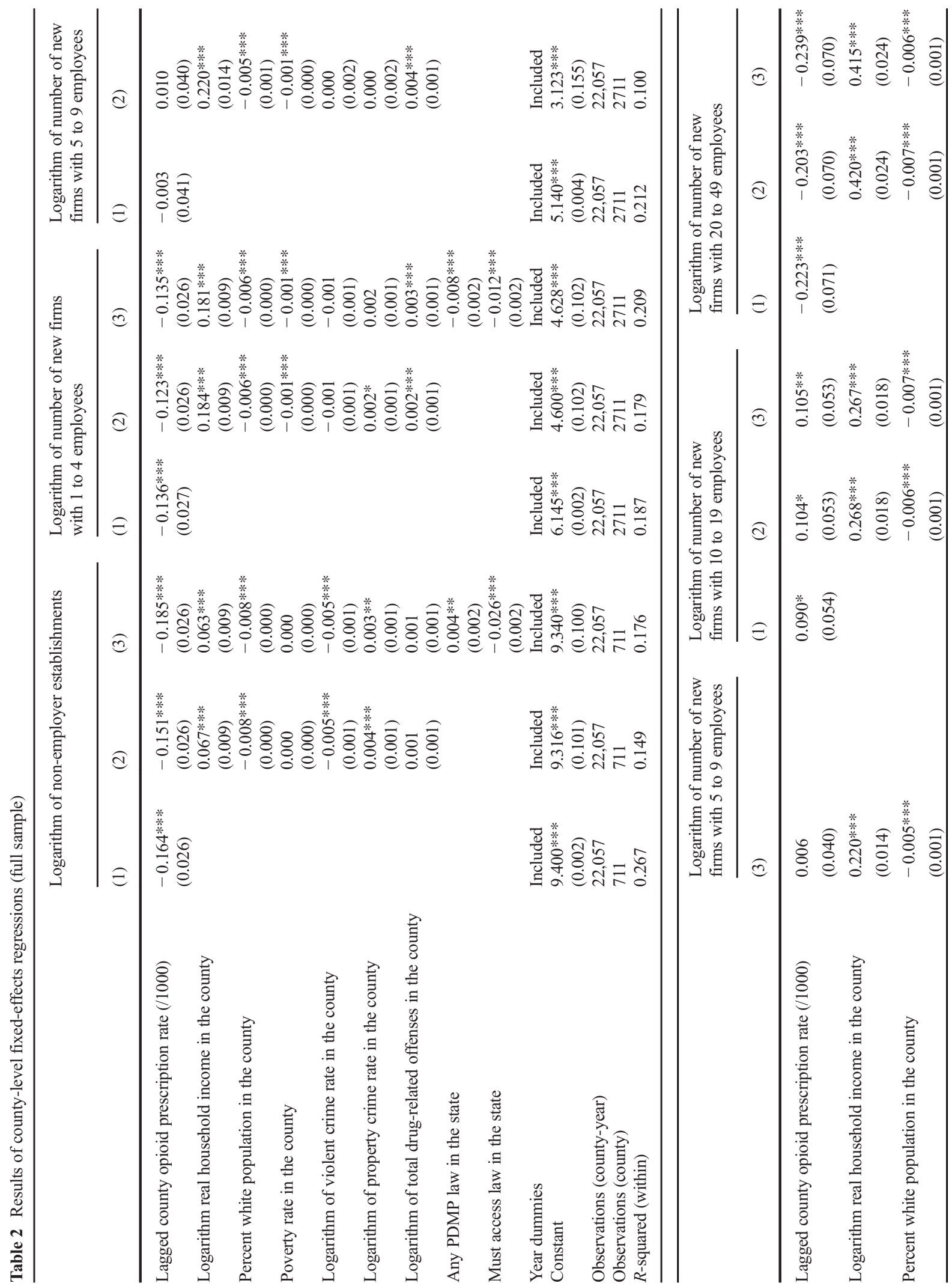




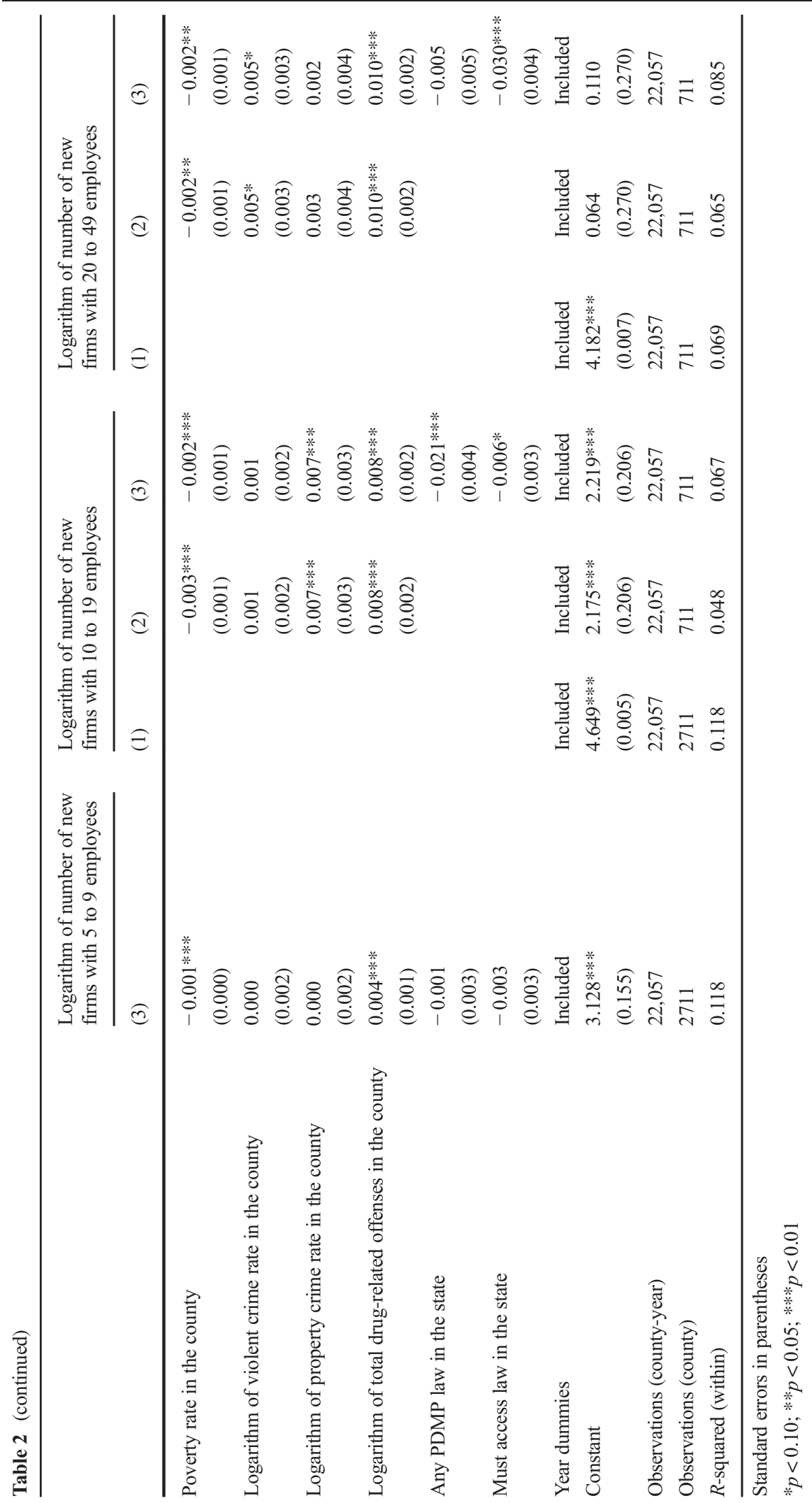


analysis (Table 4). Table 3 shows that there are some significant but small differences in means of control variables between focal and neighbor counties (Logarithm of violent crime rate in the county, Logarithm of property crime rate in the county, and Logarithm of total drug-related offenses in the county). However, we do not find significant differences in terms of other control variables nor in terms of GDP (all industries, private sector, and government). Therefore, we conclude that the results in our analysis are not likely to be driven by omitted variable bias.

Table 4 includes the fixed-effects estimates for the neighbor county-pair analysis. Model 1 includes the lagged opioid prescriptions rate and year fixed-effects, and model 2 additionally includes the county-level control variables. Model 3 complement model 2 with the neighbor county control variables, and finally, in model 4 , we include control variables for the presence of statelevel opioid laws. Overall, the effect sizes in Table 4 are somewhat smaller as compared to the results in Table 2. In model 4 , an increase of 10 opioid prescriptions per 100 people is associated with a $0.118 \%$ decline in the number of non-employer establishments. This figure translates to 13.84 fewer new non-employee establishments in an average county. A similar increase in the county-prescription rate is associated with a decline of $0.122 \%$ in the number of new firms with 1 to $4 \mathrm{em}-$ ployees ( 0.61 businesses). We do not find a significant relationship for firms with 5-9 employees, but a positive relationship for size class $10-19(0.234 \%, 0.26$ businesses). For firm size class 20-49, we find a nonsignificant relationship. Consistent with the full county sample, we broadly conclude that the number of establishments declines with higher opioid prescription rates. Effect sizes are small (and somewhat smaller than in the full sample), but relatively sizeable in absolute terms for non-employer establishments and new establishments with 1-4 employees.

In Tables 9 and 10 in the Appendix, we further explore whether the interaction between the countylevel opioid prescriptions rate and the presence of state-level opioid laws is associated with our measures for new business establishment. The presence of statelevel opioid laws may influence the opioid prescription rates in a county, but from a policy point of view, it is interesting to explore whether the association between the opioid prescription rate and new business establishment differs in the presence of state-level opioid laws. In these models, we include all county-level and neighbor county-level controls along with the year fixed effects. Additionally, we include the interaction between the opioid prescription rate with the presence of any PDMP law in the state (model 1) and the interaction between the opioid prescription rate and the presence of must access laws in the state (model 2). We find that the interaction terms are either negative or insignificant. The exception is the association between the county opioid prescription rate and the presence of a must access law in the state and new firms with 10 to 19 employees. However, this association is small in absolute terms. These negative interactions may be explained by a higher abuse of opioids in the presence of strictly enforced laws.

Our state-level analysis supplements the county-level analysis. For the state-level analysis, the fixed-effect specification is as follows:

$Y_{s t}=\alpha_{0}+\alpha_{1} O_{s t-1}+\alpha_{x} X_{s t}+\alpha_{s}+e_{s t}$,

with $Y_{s t}$ representing the entrepreneurial activity index or opportunity-based entrepreneurship in state $s$ in year $t, O_{s t-1}$ the opioid prescription rate in state $s$ in year $t, X_{s, t}$ the set of control variables (including year dummies), $\alpha_{s}$ a vector with state fixed-effects, and $e_{s, t}$ the error term. Table 5 presents the empirical results of the state-level analysis. The first model for each outcome includes the lagged opioid prescriptions rate only, and the second model additionally includes all state-level control variables (except the presence of laws for recreational cannabis use). For each outcome, in model 1, the relationship between the lagged opioid description rate and the dependent variable is significantly negative. An increase of 10 prescriptions per 100 individuals in the state is associated with a 0.117 standard deviation decline in the entrepreneurial activity index. However, this relationship is only significant at the $10 \%$ level. For the outcome variable opportunity-based entrepreneurship, the same increase in the lagged state opioid prescription rate is associated with an approximately $1 \%$ decrease in the share of entrepreneurs driven by opportunity instead of necessity. The inclusion of the control variables for recreational cannabis use (model 3 ) does not change these inferences.

\section{Discussion and conclusion}

According to a recently released report from the National Institute of Health (NIH), in 2017, an 
Table 3 Analysis of differences regarding control variables and gross domestic product between neighboring counties. Counties in each county-pair are randomly assigned to be focal or neighbor county

\begin{tabular}{|c|c|c|c|c|c|}
\hline & Counties & $\begin{array}{l}\text { Number of } \\
\text { county-year } \\
\text { observations }\end{array}$ & Mean & Standard error & $p$ value \\
\hline \multicolumn{6}{|l|}{ Control variables: } \\
\hline Any PDMP law in the state & $\begin{array}{l}\text { Focal } \\
\text { Neighbor }\end{array}$ & $\begin{array}{l}2232 \\
2161\end{array}$ & $\begin{array}{l}0.903 \\
0.892\end{array}$ & $\begin{array}{l}0.006 \\
0.007\end{array}$ & 0.227 \\
\hline Must access law in the state & $\begin{array}{l}\text { Focal } \\
\text { Neighbor }\end{array}$ & $\begin{array}{l}2232 \\
2161\end{array}$ & $\begin{array}{l}0.107 \\
0.104\end{array}$ & $\begin{array}{l}0.007 \\
0.007\end{array}$ & 0.786 \\
\hline Logarithm real household income in the county & $\begin{array}{l}\text { Focal } \\
\text { Neighbor }\end{array}$ & $\begin{array}{l}2232 \\
2161\end{array}$ & $\begin{array}{l}10.789 \\
10.788\end{array}$ & $\begin{array}{l}0.005 \\
0.005\end{array}$ & 0.801 \\
\hline Percent white population in the county & $\begin{array}{l}\text { Focal } \\
\text { Neighbor }\end{array}$ & $\begin{array}{l}2232 \\
2161\end{array}$ & $\begin{array}{l}81.085 \\
81.277\end{array}$ & $\begin{array}{l}0.353 \\
0.366\end{array}$ & 0.705 \\
\hline Poverty rate in the county & $\begin{array}{l}\text { Focal } \\
\text { Neighbor }\end{array}$ & $\begin{array}{l}2232 \\
2161\end{array}$ & $\begin{array}{l}11.920 \\
12.076\end{array}$ & $\begin{array}{l}0.110 \\
0.119\end{array}$ & 0.338 \\
\hline Logarithm of violent crime rate in the county & $\begin{array}{l}\text { Focal } \\
\text { Neighbor }\end{array}$ & $\begin{array}{l}2232 \\
2161\end{array}$ & $\begin{array}{l}5.161 \\
5.191\end{array}$ & $\begin{array}{l}0.019 \\
0.019\end{array}$ & 0.027 \\
\hline Logarithm of property crime rate in the county & $\begin{array}{l}\text { Focal } \\
\text { Neighbor }\end{array}$ & $\begin{array}{l}2232 \\
2161\end{array}$ & $\begin{array}{l}7.430 \\
7.485\end{array}$ & $\begin{array}{l}0.016 \\
0.015\end{array}$ & 0.022 \\
\hline Logarithm of total drug-related offenses in the county & $\begin{array}{l}\text { Focal } \\
\text { Neighbor }\end{array}$ & $\begin{array}{l}2232 \\
2161\end{array}$ & $\begin{array}{l}4.801 \\
4.934\end{array}$ & $\begin{array}{l}0.036 \\
0.036\end{array}$ & 0.009 \\
\hline \multicolumn{6}{|l|}{ Gross domestic product: } \\
\hline Logarithm of real GDP (all industries) & $\begin{array}{l}\text { Focal } \\
\text { Neighbor }\end{array}$ & $\begin{array}{l}743 \\
715\end{array}$ & $\begin{array}{l}14.016 \\
14.047\end{array}$ & $\begin{array}{l}0.054 \\
0.052\end{array}$ & 0.687 \\
\hline Logarithm of real GDP (private sector) & $\begin{array}{l}\text { Focal } \\
\text { Neighbor }\end{array}$ & $\begin{array}{l}730 \\
701\end{array}$ & $\begin{array}{l}12.709 \\
12.777\end{array}$ & $\begin{array}{l}0.051 \\
0.051\end{array}$ & 0.349 \\
\hline Logarithm of real GDP (government) & $\begin{array}{l}\text { Focal } \\
\text { Neighbor }\end{array}$ & $\begin{array}{l}743 \\
715\end{array}$ & $\begin{array}{l}12.067 \\
12.086\end{array}$ & $\begin{array}{l}0.053 \\
0.050\end{array}$ & 0.802 \\
\hline
\end{tabular}

$p$ value reflects the result of a two-sided test for a difference in means between focal and neighbor counties. County-level gross domestic product (GDP) data were only released recently for 2012-2015 by the US Bureau for Economic Analysis (https://www.bea. gov/data/gdp/gdp-county)

estimated 1.7 million people suffered from substance use disorders related to prescription opioid pain relievers in the USA (National Institute on Drug Abuse 2018). Despite the small prevalence rate at the population rate, the direct and indirect effects are devastating, so much so that the current federal administration declared prescription opioid abuse as a national health emergency. Though recent studies have focused on the influence of prescription opioids on labor market outcomes, we focused in this study on the impact on new business formation.

In addition to the health, social, and emotional costs, our analyses at the county-level show that there is a small but significant negative relationship between the rate of opioid prescriptions and nonemployer establishments and new firm establishments with 1-4 employees even after controlling for both county-level and neighbor county conditions. We also find a positive significant relationship with the number of new businesses with 10-19 employees (in the full sample as well as in the neighbor county-pair sample) and a negative relationship with the number of new business with 20 49 employees (full county sample only). However, in absolute terms, these latter relationships are small. The state-level analyses complement these results by showing that also at the state level, there is a small but significant relationship between the opioid prescription rate and new business formation (in particular opportunity-based as opposed to necessitydriven entrepreneurship). Although freelancers and contractors represent a significant portion of the non-employer establishments, the county-level and state-level results together suggest that the switch to 


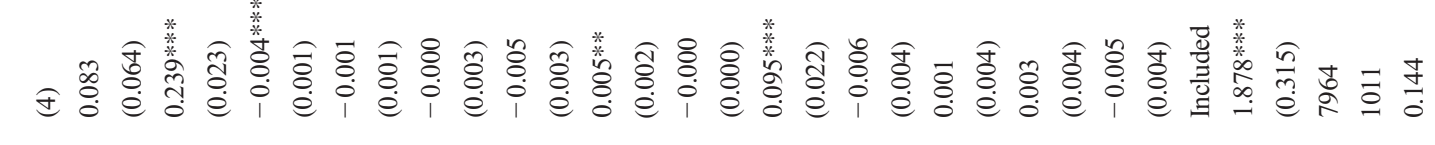

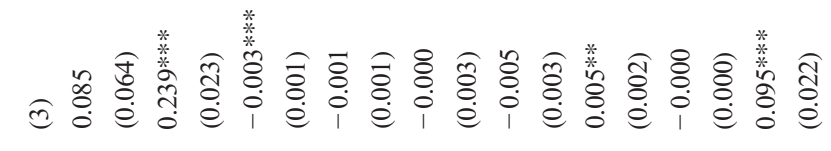

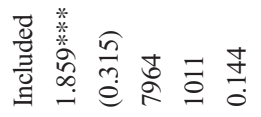

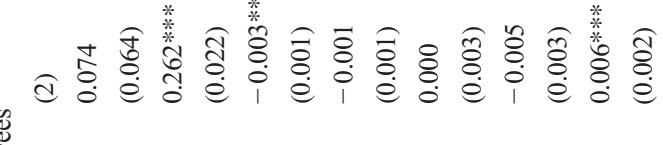

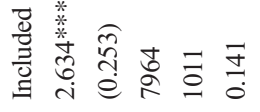

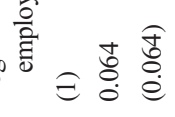

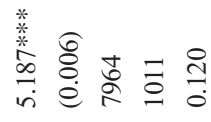

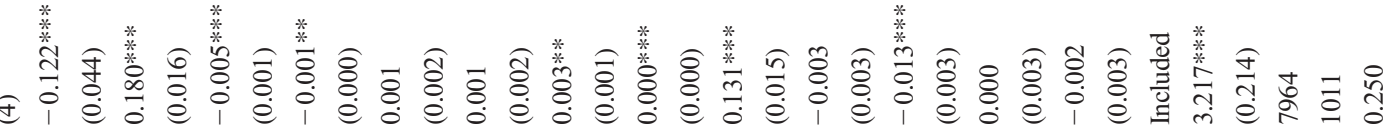

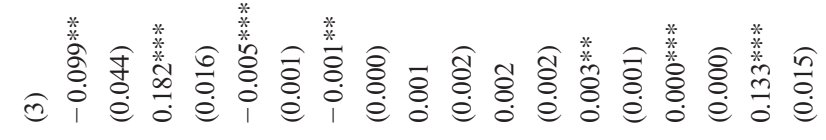

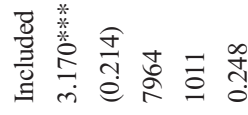

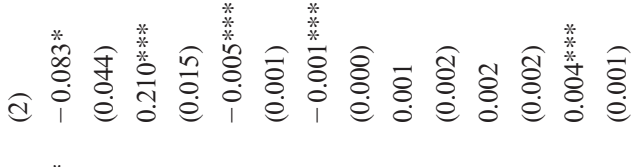

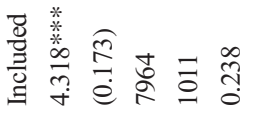

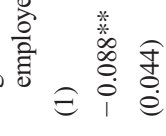

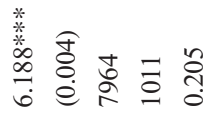

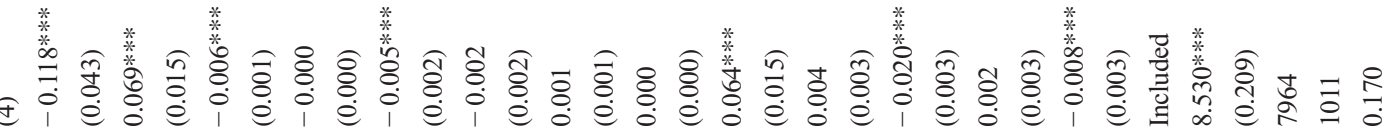

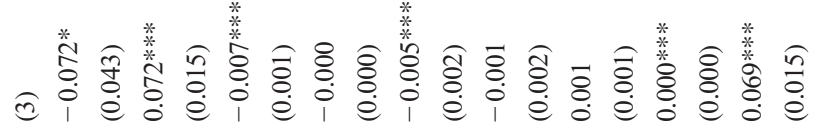

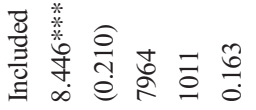

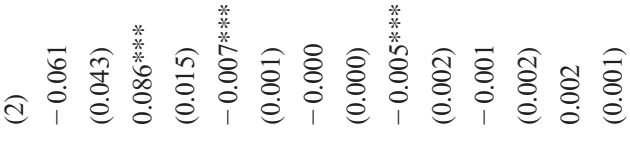

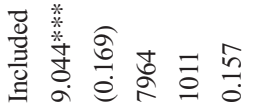

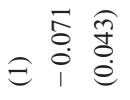

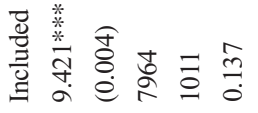




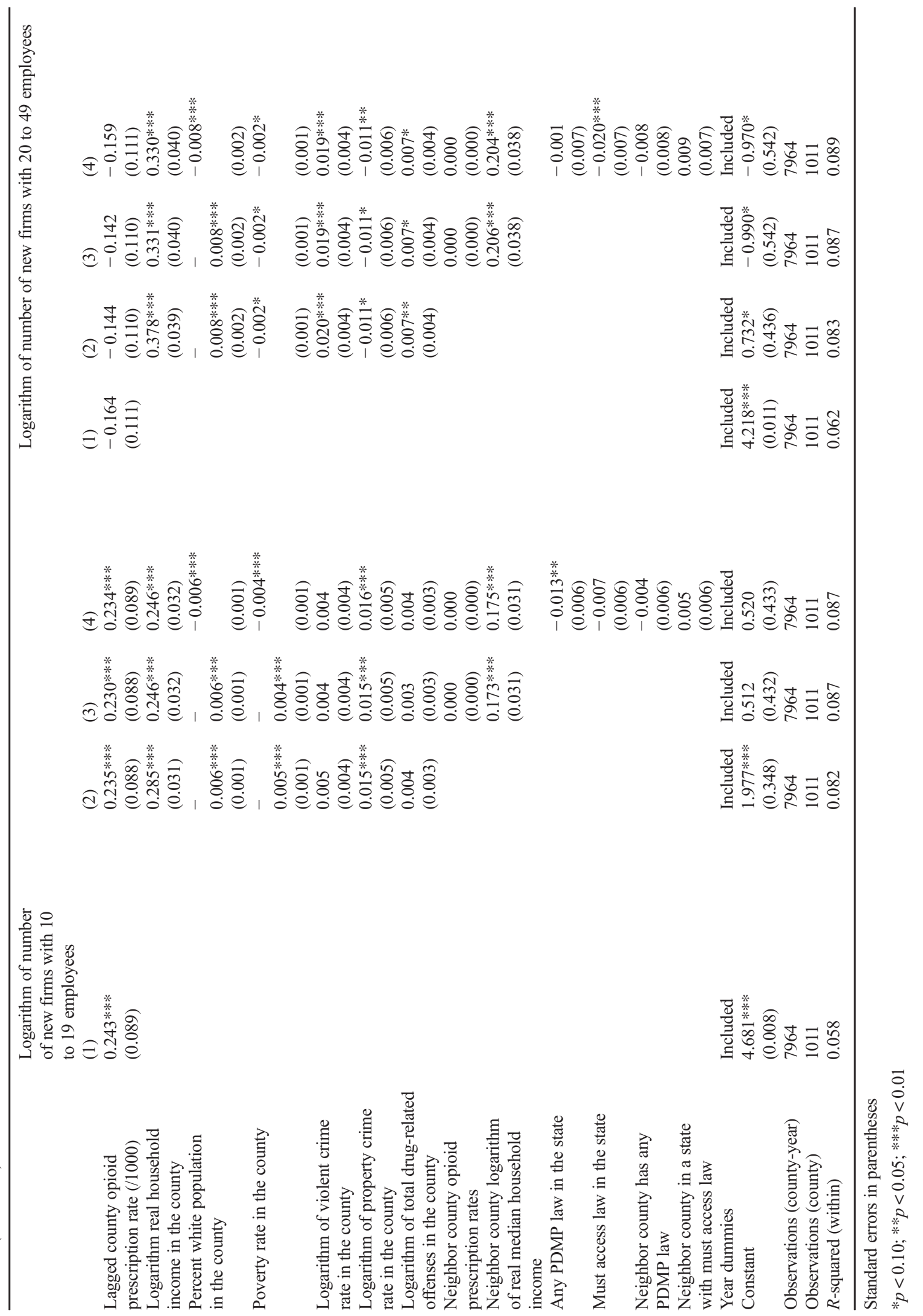


Table 5 Results of state-level fixed-effects regressions

\begin{tabular}{|c|c|c|c|c|c|c|}
\hline \multirow[t]{2}{*}{ Outcome variable: } & \multicolumn{3}{|c|}{ Entrepreneurial activity index } & \multicolumn{3}{|c|}{ Opportunity-based entrepreneurship } \\
\hline & (1) & $(2)$ & (3) & $(1)$ & $(2)$ & (3) \\
\hline Lagged state opioid prescription rate (/1000) & $\begin{array}{l}-14.590 * * \\
(6.895)\end{array}$ & $\begin{array}{l}-13.145^{*} \\
(6.852)\end{array}$ & $\begin{array}{l}-11.681 * \\
(6.909)\end{array}$ & $\begin{array}{l}-1.117^{* *} \\
(0.473)\end{array}$ & $\begin{array}{l}-1.058^{* *} \\
(0.463)\end{array}$ & $\begin{array}{l}-1.037^{* *} \\
(0.468)\end{array}$ \\
\hline Logarithm of gross state product & & $\begin{array}{l}-1.601 * \\
(0.966)\end{array}$ & $\begin{array}{l}-1.227 \\
(0.995)\end{array}$ & & $\begin{array}{l}0.129 * * \\
(0.065)\end{array}$ & $\begin{array}{l}0.134 * * \\
(0.067)\end{array}$ \\
\hline Logarithm of state personal income & & $\begin{array}{l}1.130 \\
(1.576)\end{array}$ & $\begin{array}{l}0.450 \\
(1.635)\end{array}$ & & $\begin{array}{l}0.074 \\
(0.106)\end{array}$ & $\begin{array}{l}0.064 \\
(0.111)\end{array}$ \\
\hline Poverty rate & & $\begin{array}{l}-0.014 \\
(0.025)\end{array}$ & $\begin{array}{l}-0.014 \\
(0.025)\end{array}$ & & $\begin{array}{l}-0.005^{* * * *} \\
(0.002)\end{array}$ & $\begin{array}{l}-0.005^{* * * *} \\
(0.002)\end{array}$ \\
\hline Governor is democrat & & $\begin{array}{l}0.177 * * \\
(0.082)\end{array}$ & $\begin{array}{l}0.178 * * \\
(0.082)\end{array}$ & & $\begin{array}{l}-0.000 \\
(0.006)\end{array}$ & $\begin{array}{l}-0.000 \\
(0.006)\end{array}$ \\
\hline State EITC rate & & $\begin{array}{l}1.119 * * \\
(0.544)\end{array}$ & $\begin{array}{l}0.950 * \\
(0.554)\end{array}$ & & $\begin{array}{l}0.047 \\
(0.037)\end{array}$ & $\begin{array}{l}0.044 \\
(0.038)\end{array}$ \\
\hline State minimum wage & & $\begin{array}{l}0.084 \\
(0.060)\end{array}$ & $\begin{array}{l}0.066 \\
(0.061)\end{array}$ & & $\begin{array}{l}0.003 \\
(0.004)\end{array}$ & $\begin{array}{l}0.003 \\
(0.004)\end{array}$ \\
\hline Logarithm of AFDC and TANF caseloads & & $\begin{array}{l}-0.037 \\
(0.131)\end{array}$ & $\begin{array}{l}-0.076 \\
(0.133)\end{array}$ & & $\begin{array}{l}-0.009 \\
(0.009)\end{array}$ & $\begin{array}{l}-0.009 \\
(0.009)\end{array}$ \\
\hline Logarithm of population & & $\begin{array}{l}-3.146 \\
(2.779)\end{array}$ & $\begin{array}{l}-3.521 \\
(2.786)\end{array}$ & & $\begin{array}{l}0.139 \\
(0.188)\end{array}$ & $\begin{array}{l}0.133 \\
(0.189)\end{array}$ \\
\hline Logarithm of employment & & $\begin{array}{l}5.936 * * * \\
(2.236)\end{array}$ & $\begin{array}{l}6.112 * * * \\
(2.236)\end{array}$ & & $\begin{array}{l}0.051 \\
(0.151)\end{array}$ & $\begin{array}{l}0.054 \\
(0.151)\end{array}$ \\
\hline Recreational cannabis law & & & $\begin{array}{l}0.348 \\
(0.227)\end{array}$ & & & $\begin{array}{l}0.005 \\
(0.015)\end{array}$ \\
\hline Year dummies & Included & Included & Included & Included & Included & Included \\
\hline Constant & $\begin{array}{l}1.161 * * \\
(0.503)\end{array}$ & $\begin{array}{l}-39.128 \\
(27.324)\end{array}$ & $\begin{array}{l}-27.243 \\
(28.362)\end{array}$ & $\begin{array}{l}0.921 * * * \\
(0.035)\end{array}$ & $\begin{array}{l}-4.836^{* * * *} \\
(1.847)\end{array}$ & $\begin{array}{l}-4.660 * * \\
(1.921)\end{array}$ \\
\hline$N$ (state-year) & 547 & 547 & 547 & 547 & 547 & 547 \\
\hline$N$ (state) & 50 & 50 & 50 & 50 & 50 & 50 \\
\hline$R$-squared (within) & 0.256 & 0.298 & 0.301 & 0.276 & 0.337 & 0.338 \\
\hline
\end{tabular}

Standard errors in parentheses

$* p<0.10 ; * * p<0.05 ; * * * p<0.01$

non-employer firms may not be due to necessitydriven entrepreneurship (individuals switching to self-employment after losing their job due to opioid usage). Therefore, overall, we conclude that the relationship between the opioids prescription rate and new business formation is negative.

These findings are of particular interest to policymakers. With the opioid crisis at the center stage of political debate and recent works highlighting the negative implications for the labor market, the current findings support the need to focus on the small and negative influence of opioid prescriptions on new business activity. For comparison, Harris et al. (2019) find that a $10 \%$ increase in prescriptions reduces labor force participation by $0.56 \%$. We find that an increase of 10 opioid prescriptions per 100 people is associated with a $0.12 \%$ decline in the number of nonemployer establishments. With non-employer firms representing about three-quarters of the 30.2 million small businesses in the USA (Small Business 
Administration 2018), a $0.12 \%$ decline in nonemployer firms translates to about 27,000 fewer non-employer firms. Hence, although these declines seem relatively small from a percentage point of view, they are practically meaningful in terms of absolute numbers. Over time, these declines could have a long-term detrimental impact on the overall entrepreneurial activity of regions by lowering entrepreneurial efficacy and competitiveness. We call on policymakers to consider the negative impact of opioid prescriptions on new business activity in their efforts to tackle the opioid crisis. Moreover, because of the significant interactions we find between the opioid prescription rates and the presence of state-level opioid laws, a system approach will be needed to project what can be expected with and without interventions (Phillips et al. 2017).

With our focus on entrepreneurial activity and new business formation of in particular relatively small firms, we analyzed different labor market characteristics than Harris et al. (2019), Currie et al. (2019), and Aliprantis et al. (2019). We enrich their findings that opioid prescription rates are negatively related to labor force participation rates, employment-to-population ratios, and unemployment rates by providing additional evidence that higher opioid description rates primarily make individuals leave the labor force as there seems to be only a weak relationship with new business formation. Our state-level analysis demonstrates a decline in entrepreneurial activity, especially opportunity-driven entrepreneurship. Because opportunity-based entrepreneurship is the core of economic growth, and the general support for a decline in the general entrepreneurial activity, the reverberations of opioid prescriptions seem to go beyond the labor force and influence also the composition of the business population. Because of the relationship between entrepreneurship and economic growth, it seems also plausible to conclude that the opioid crisis will also hamper economic growth in the long run.

Although county-pair analyses have particular advantages, as described in Sects. 3.1 and 3.4, future studies on opioids use and entrepreneurial activity may take an individual-level approach which might be able to reveal particular channels through which opioid use influences business start-up. In such a setup, it will be important to distinguish the use and misuse. Due to the Health Insurance Portability and Accountability Act of 1996 (HIPPA) restrictions, disaggregated data may be difficult to collate even from the confidential U.S. Census data or the Center for Disease Control (CDC) data. Finally, we note that there may be many complexities in the relationship between opioid abuse and entrepreneurial activity which we could not explore in the context of this study. For example, the legal context may also indirectly influence new business formation. Fairlie (2002) has shown that drug dealing in youth increases the probability to engage in self-employment in later life. Longitudinal individual level would also make it possible to analyze these types of relationships over time.

Although the County Business Patterns data is a reliable source providing information on year-to-year firm establishments, identifying year-to-year business closures is difficult to identify at the countylevel from the publicly available data sources. Still, we believe that the analysis of aggregated data on business closure is an important direction for future research for two reasons. First of all, the abuse of opioids by business owners is likely to lower business focus and increase the hazard of business failure. Still, widespread abuse of opioids may also make those low-performing business owners survive in the market because of a deteriorated business environment (lower competition). Second, relatedly, a general decline in human capital and financial conditions because of opioid abuse may lower the quality of human capital inputs. Therefore, the likelihood of re-entry after business closure or business failure may reduce, which may also have consequences for the general business environment. Therefore, in addition to the relationship between opioid prescription rates and new business establishment explored here, we consider the investigation of business closures driven by opioid abuse to be an important direction for future research. 


\section{Appendix}
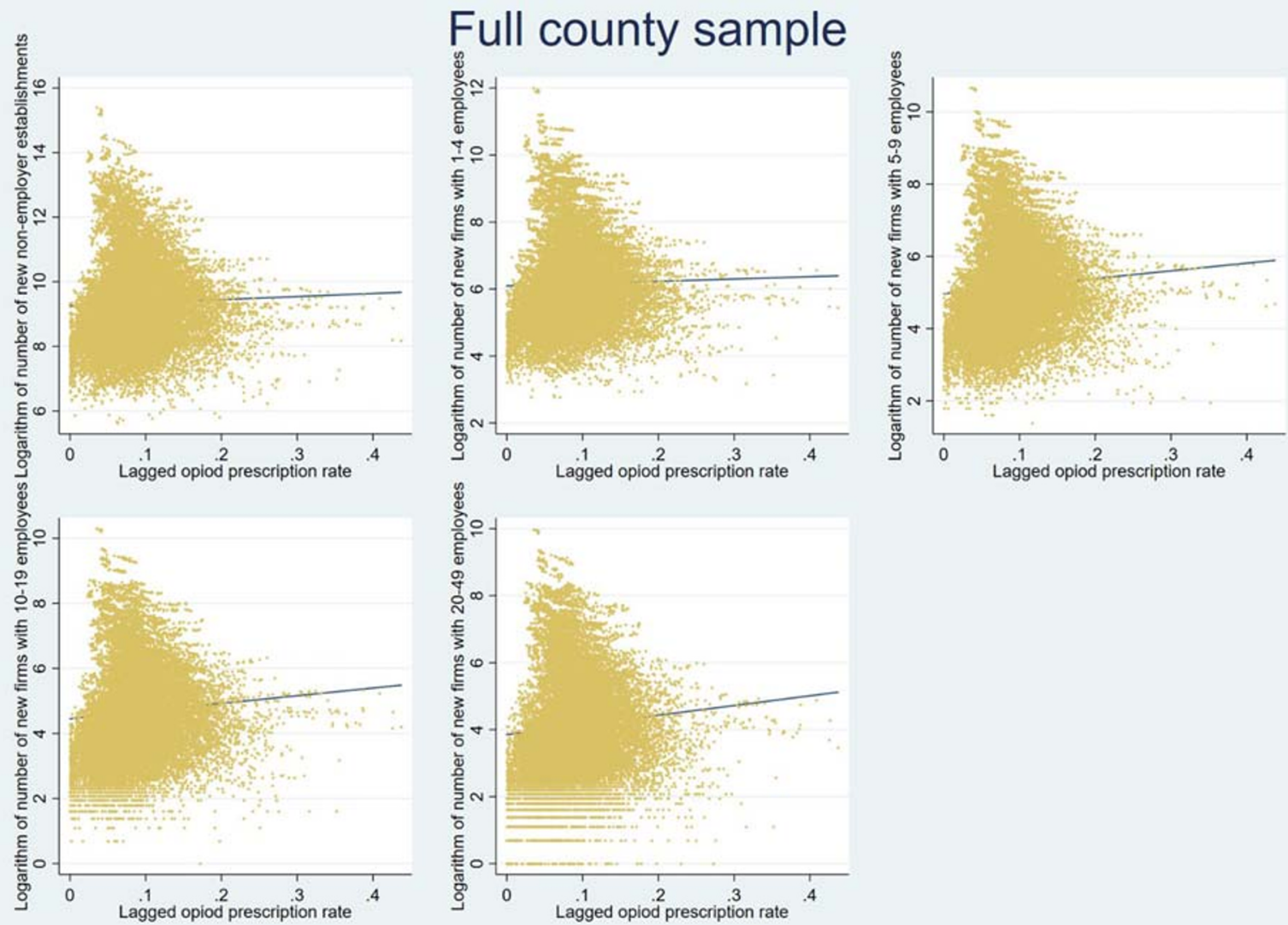

Fig. 1 The relationship between the lagged opioid prescription rate and new business formation in the county-level sample (full sample) 

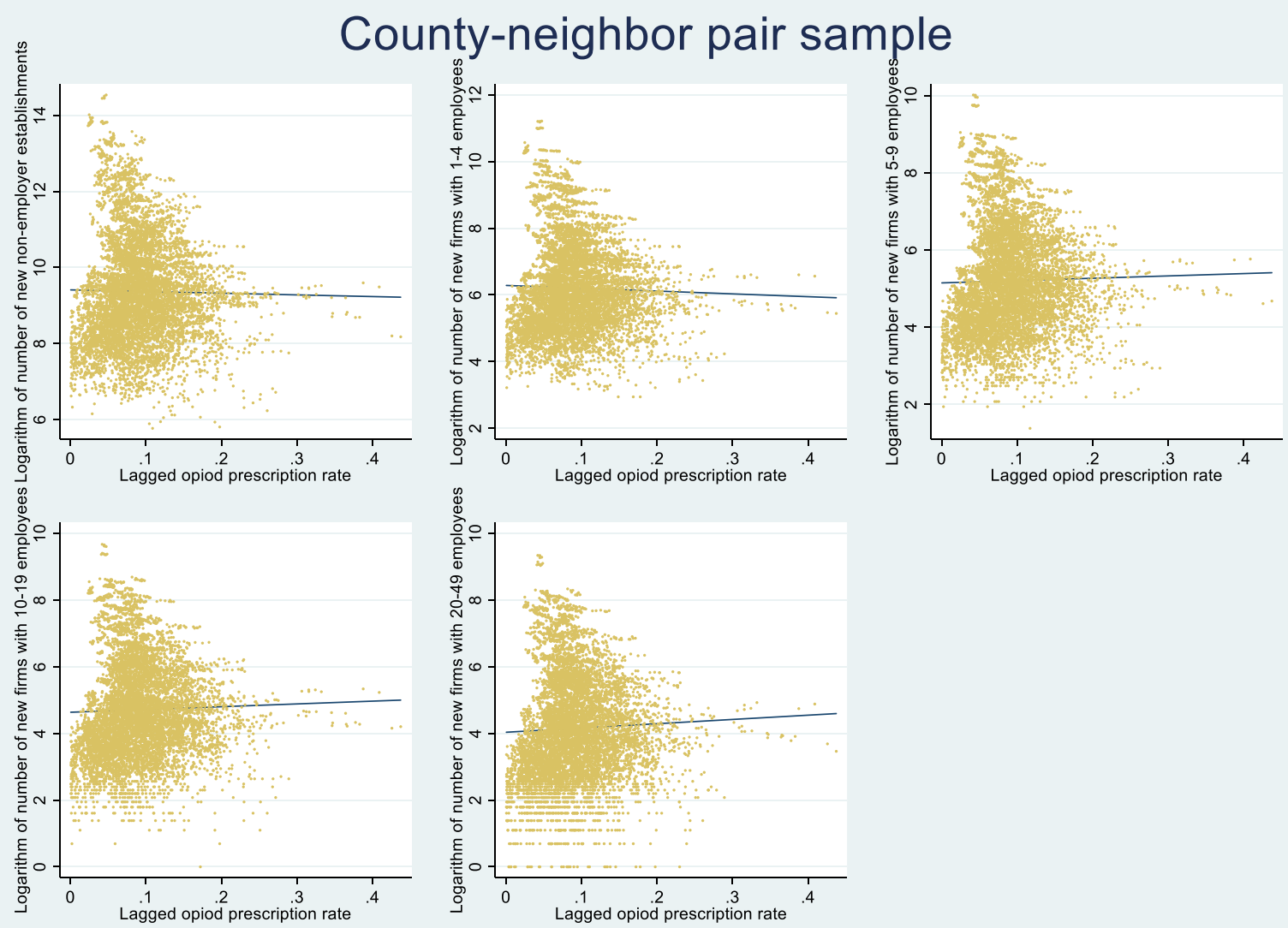

Fig. 2 The relationship between the lagged opioid prescription rate and new business formation in the county-level sample (neighbor county-pair subsample) 
Fig. 3 The relationship between the lagged opioid prescription rate and entrepreneurial activity in the state-level sample

\section{Entrepreneurial activity index}

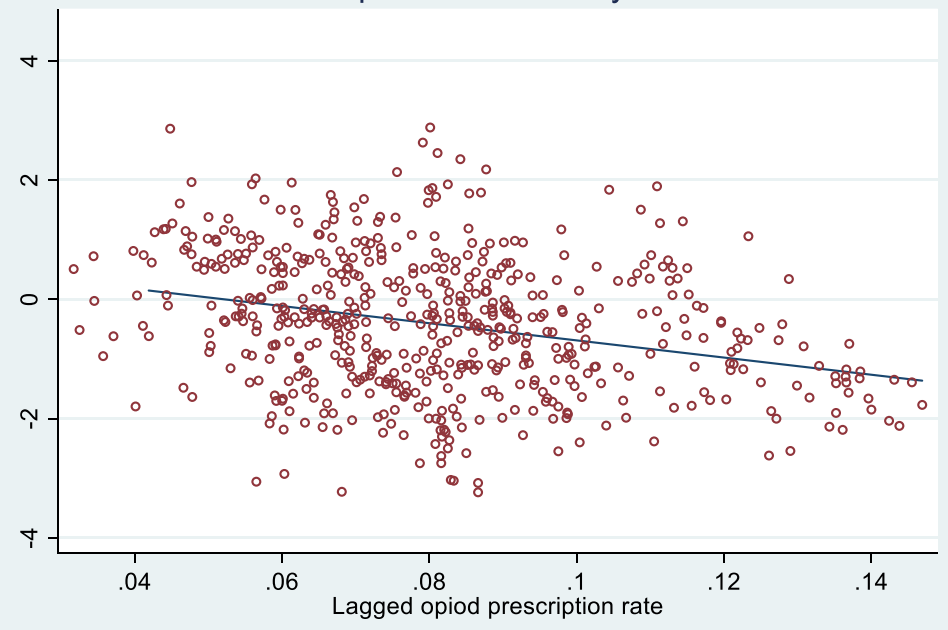

Opportunity based entrepreneurship

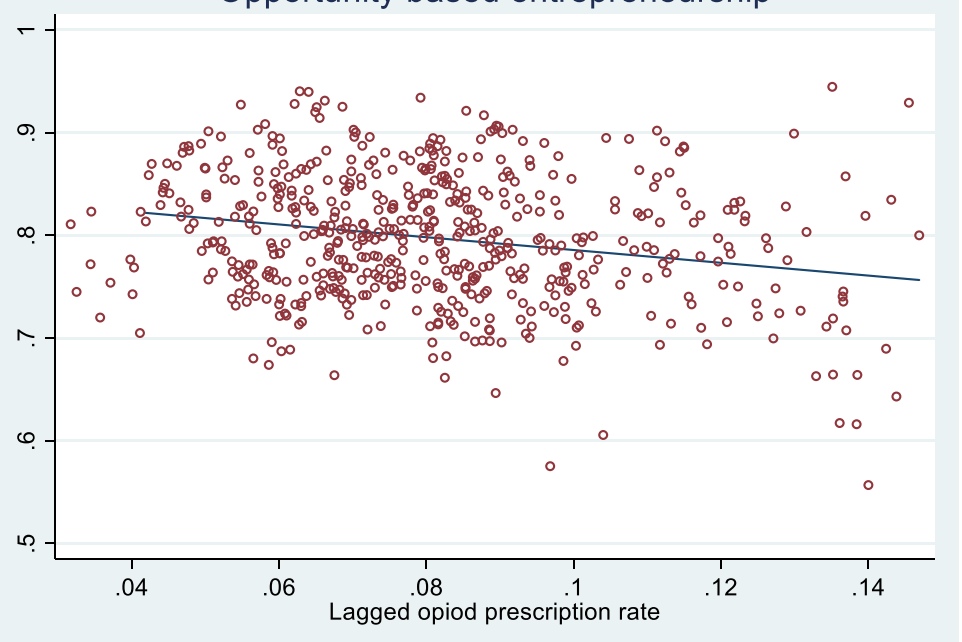




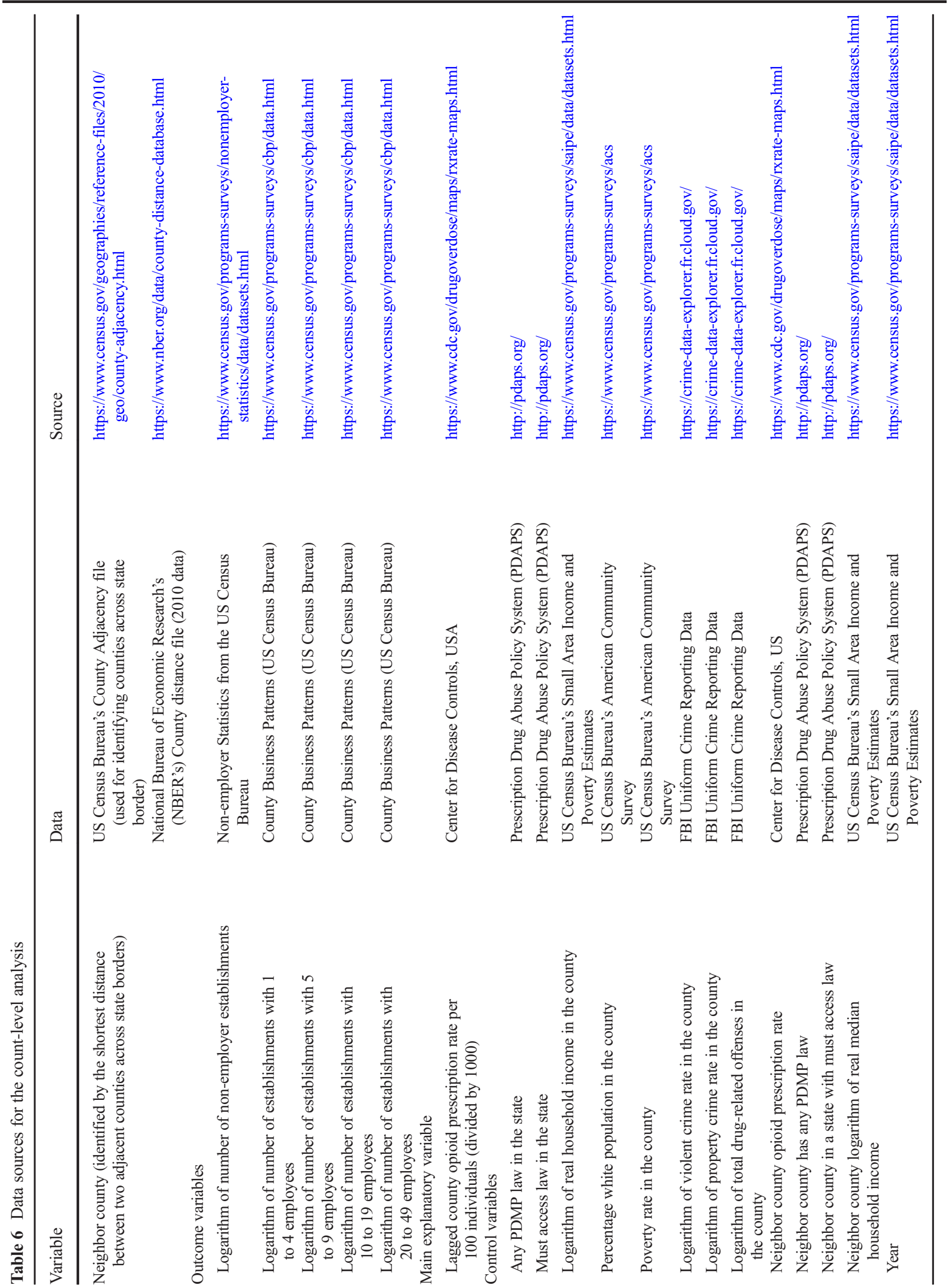


Table 7 States with "must access law," meaning that the state requires prescribers and dispensers to check the Prescription Drug Monitoring Program before prescribing controlled substances (1998 and 2016). Source: Prescription Drug Abuse Policy System (PDAPS.org)

\begin{tabular}{ll}
\hline State & Year must access law was enacted \\
\hline Connecticut & 2015 \\
Indiana & 2014 \\
Kentucky & 2012 \\
Louisiana & 2014 \\
Massachusetts & 2014 \\
Nevada & 2015 \\
New Jersey & 2015 \\
New Mexico & 2012 \\
New York & 2013 \\
Ohio & 2015 \\
Oklahoma & 2015 \\
Pennsylvania & 2015 \\
Tennessee & 2013 \\
Vermont & 2015 \\
Virginia & 2015 \\
West Virginia & 2012 \\
\hline
\end{tabular}

Due to space limitations, the table only provides the listing of must access laws. Comprehensive information about a variety of PDMP laws and their year of passage are available at http://pdaps. org/datasets/prescription-monitoring-program-laws-14082234161502818373

Table 8 Data sources for the state-level analysis

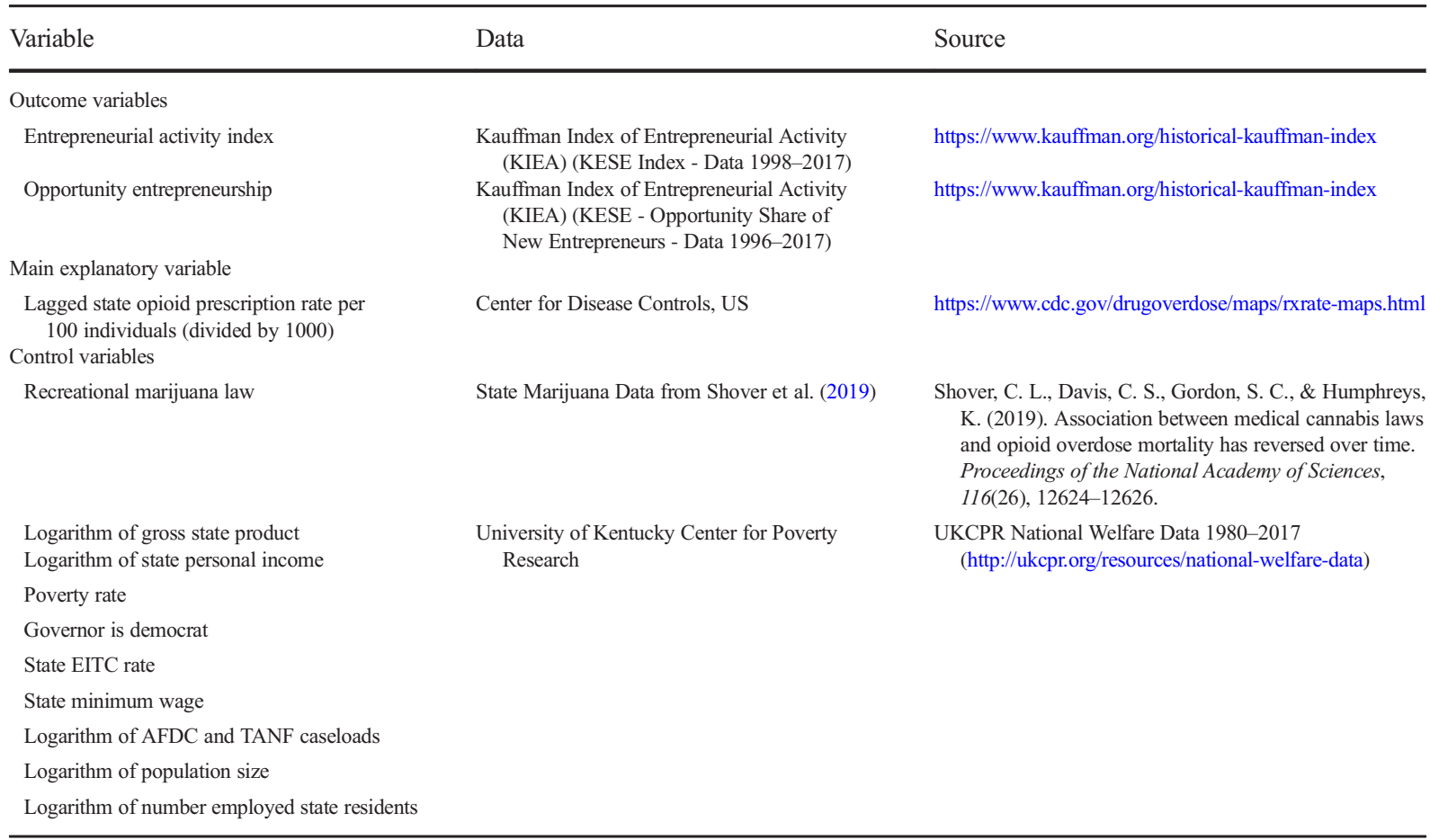




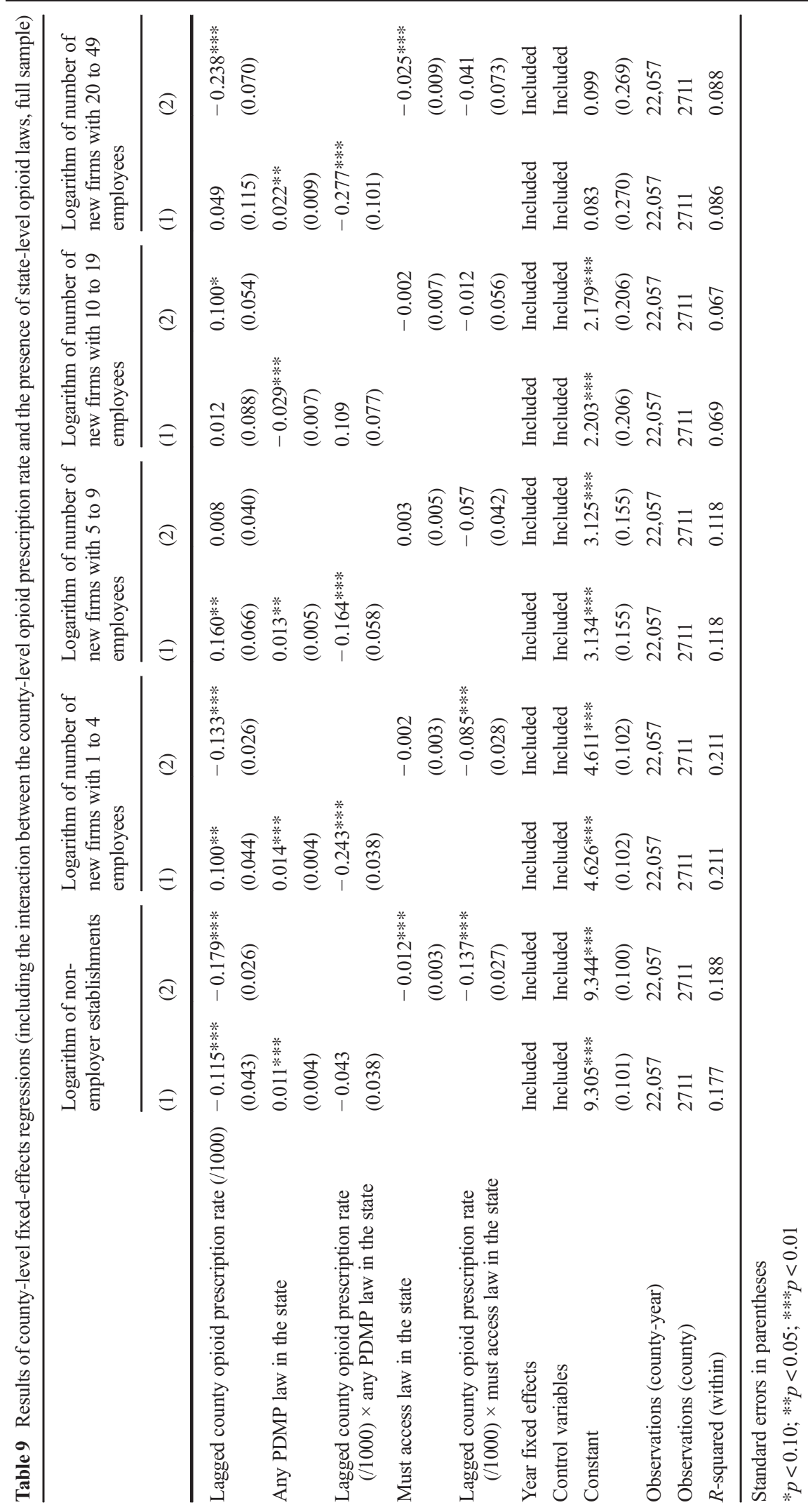




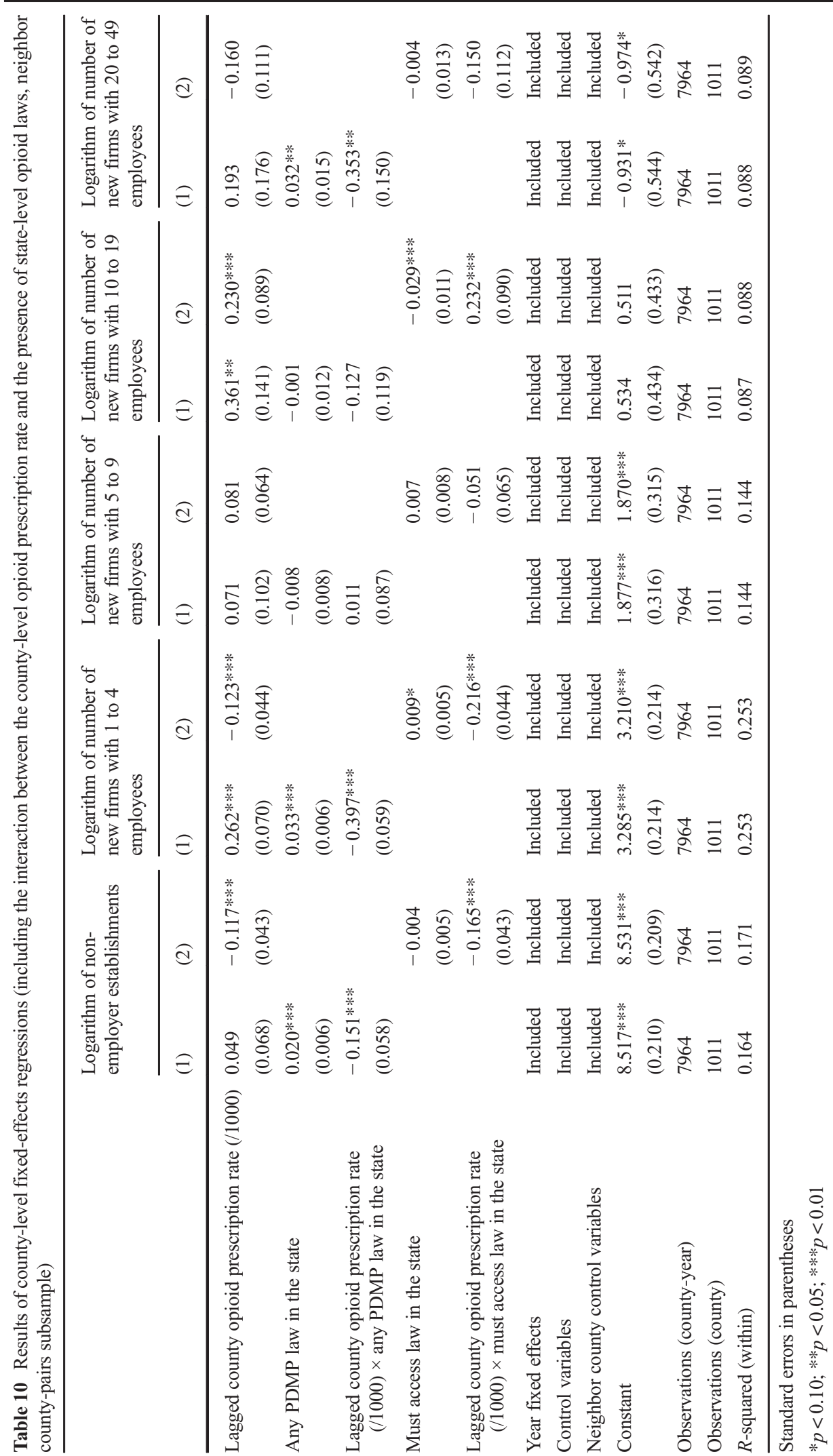


Open Access This article is licensed under a Creative Commons Attribution 4.0 International License, which permits use, sharing, adaptation, distribution and reproduction in any medium or format, as long as you give appropriate credit to the original author(s) and the source, provide a link to the Creative Commons licence, and indicate if changes were made. The images or other third party material in this article are included in the article's Creative Commons licence, unless indicated otherwise in a credit line to the material. If material is not included in the article's Creative Commons licence and your intended use is not permitted by statutory regulation or exceeds the permitted use, you will need to obtain permission directly from the copyright holder. To view a copy of this licence, visit http://creativecommons.org/licenses/by/4.0/.

\section{References}

Acs, Z. J., \& Armington, C. (2006). Entrepreneurship, geography, and American economic growth. Cambridge: Cambridge University Press.

Aghion, P., Howitt, P., \& Murtin, F. (2010). The relationship between health and growth: when Lucas meets NelsonPhelps. National Bureau of Economic Research. https://doi. org/10.3386/w15813.

Aliprantis, D., Fee, K., \& Schweitzer, M. E. (2019). Opioids and the labor market FRB of Cleveland Working Paper No. 1807R, Available at SSRN: https://ssrn.com/abstract $=3179068$ or $\mathrm{https}$ ://doi.org/10.2139/ssrn.3179068

Barnett, M. L., Olenski, A. R., \& Jena, A. B. (2017). Opioidprescribing patterns of emergency physicians and risk of long-term use. New England Journal of Medicine, 376(7), 663-673. https://doi.org/10.1056/NEJMsa1610524.

Becker, G. (1964). Human capital. New York: Columbia Univ. press (for Nat. Bur. Econ. Res.).

Bhargava, A., Jamison, D. T., Lau, L. J., \& Murray, C. J. (2001). Modeling the effects of health on economic growth. Journal of Health Economics, 20(3), 423-440. https://doi. org/10.1016/S0167-6296(01)00073-X.

Birnbaum, H. G., White, A. G., Schiller, M., Waldman, T., Cleveland, J. M., \& Roland, C. L. (2011). Societal costs of prescription opioid abuse, dependence, and misuse in the United States. Pain Medicine, 12(4), 657-667. https://doi. org/10.1111/j.1526-4637.2011.01075.x.

Bloom, D. E., Canning, D., \& Sevilla, J. (2004). The effect of health on economic growth: a production function approach. World Development, 32(1), 1-13. https://doi.org/10.1016/j. worlddev.2003.07.002.

Buchmueller, T. C., \& Carey, C. (2018). The effect of prescription drug monitoring programs on opioid utilization in Medicare. American Economic Journal: Economic Policy, 10(1), 77112. https://doi.org/10.1257/pol.20160094.

Buttner, E. H. (1992). Entrepreneurial stress: Is it hazardous to your health? Journal of Managerial Issues, 4(2), 223-240 https://www.jstor.org/stable/40603932.

Cai, L., \& Kalb, G. (2006). Health status and labour force participation: evidence from Australia. Health Economics, 15(3), 241-261. https://doi.org/10.1002/hec. 1053.
Center for Disease Control (2017). Opioid overdose: understanding the epidemic (https://www.cdc.gov/drugoverdose/ epidemic/index.html).

Currie, J., Jin, J., \& Schnell, M. (2019). US employment and opioids: is there a connection? In Health and labor markets (Research in labor economics, Vol. 47) (pp. 253-280). Emerald Publishing Limited. https://doi.org/10.1108/S0147912120190000047009.

Dasgupta, N., Beletsky, L., \& Ciccarone, D. (2018). Opioid crisis: no easy fix to its social and economic determinants. American Journal of Public Health, 108(2), 182-186. https://doi.org/10.2105/AJPH.2017.304187.

Doleac, J. L. and Mukherjee, A. 2018. The moral hazard of lifesaving innovations: naloxone access, opioid abuse, and crime. Available at SSRN: https://ssrn.com/abstract=3135264 or https://doi.org/10.2139/ssrn.3135264

Dube, A., Lester, T. W., \& Reich, M. (2010). Minimum wage effects across state borders: estimates using contiguous counties. The Review of Economics and Statistics, 92(4), 945-964. https://doi.org/10.1162/REST_a_00039.

Fairlie, R. W. (2002). Drug dealing and legitimate self-employment. Journal of Labor Economics, 20(3), 538-537. https://doi.org/10.1086/339610.

Fairlie, R. W. (2013). Kauffman index of entrepreneurial activity 1996-2012. Available at SSRN 2256032.

Florence, C., Luo, F., Xu, L., \& Zhou, C. (2016). The economic burden of prescription opioid overdose, abuse and dependence in the United States, 2013. Medical Care, 54(10), 901906. https://doi.org/10.1097/MLR.0000000000000625.

Florida, R. (1995). Toward the learning region. Futures, 27(5), 527-536. https://doi.org/10.1016/0016-3287(95)00021-N.

Grossman, M. (1972). On the concept of health capital and the demand for health. Journal of Political Economy, 80(2), 223255 Doi: Stable URL: http://www.jstor.org/stable/1830580.

Harris, M. C., Kessler, L. M., Murray, M. N., \& Glenn, B. (2019). Prescription opioids and labor market pains: the effect of schedule II opioids on labor force participation and unemployment. Journal of Human Resources, 1017-9093R1012. https://doi.org/10.3368/jhr.55.4.1017-9093R2.

Hessels, J., Rietveld, C. A., Thurik, A. R., \& Van der Zwan, P. (2018). Depression and entrepreneurial exit. Academy of Management Perspectives, 32(3), 323-339. https://doi. org/10.5465/amp.2016.0183.

Holmes, T. J. (1998). The effect of state policies on the location of manufacturing: evidence from state borders. Journal of Political Economy, 106(4), 667-705. https://doi. org/10.1086/250026.

Howitt, P. (2005). Health, human capital, and economic growth: a Schumpeterian perspective. Health and economic growth: findings and policy implications, 19-40.

Kauffman Foundation (2018). Kauffman indicators of entrepreneurship (Available at: https://people.ucsc.edu/ rfairlie/ data/microdata/).

Knowles, S., \& Owen, P. D. (1997). Education and health in an effective-labour empirical growth model. Economic Record, 73(223), 314-328. https://doi.org/10.1111/j.1475-4932.1997. tb01005.x.

Leibowitz, A. A. (2004). The demand for health and health concerns after 30 years. Journal of Health Economics, 23(4), 663-671. https://doi.org/10.1016/j.jhealeco.2004.04.005. 
Levesque, M., \& Minniti, M. (2006). The effect of aging on entrepreneurial behavior. Journal of Business Venturing, 21(2), 177-194. https://doi.org/10.1016/j.jbusvent.2005.04.003.

Meyer, R., Patel, A. M., Rattana, S. K., Quock, T. P., \& Mody, S. H. (2014). Prescription opioid abuse: a literature review of the clinical and economic burden in the United States. Population Health Management, 17(6), 372-387. https://doi.org/10.1089/pop.2013.0098.

Miranda, J., \& Zolas, N. (2017). Measuring the impact of household innovation using non employer administrative data. In In Measuring and accounting for innovation in the 21st century. Chicago: University of Chicago Press.

National Institute on Drug Abuse (2018). Opioid overdose crisis. Available at: https://www.drugabuse.gov/drugsabuse/opioids/opioid-overdose-crisis (Ed.).

Packham, A. (2019). Are syringe exchange programs helpful or harmful? New evidence in the wake of the opioid epidemic. Working paper. Available at: https://apackham.github. io/mywebsite/opioidpaper_webcopy.pdf

Phillips, J. K., Ford, M. A., Bonnie, R. J., \& National Academies of Sciences, E., \& Medicine. (2017). Evidence on strategies for addressing the opioid epidemic. In Pain management and the opioid epidemic: balancing societal and individual benefits and risks of prescription opioid use. National Academies Press (US).

Reinhart, M., Scarpati, L. M., Kirson, N. Y., Patton, C., Shak, N., \& Erensen, J. G. (2018). The economic burden of abuse of prescription opioids: a systematic literature review from 2012 to 2017. Applied Health Economics and Health Policy, 16(5), 609-632. https://doi.org/10.1007/s40258-018-0402-X.

Rietveld, C. A., Van Kippersluis, H., \& Thurik, A. R. (2015). Selfemployment and health: barriers or benefits? Health Economics, 24(10), 1302-1313. https://doi.org/10.1002 /hec.3087.

Schnell, M. (2017). Physician behavior in the presence of a secondary market: the case of prescription opioids. Mimeo: University of Princeton Available at: https:/www.brown. edu/academics/economics/sites/brown.edu.academics. economics/files/uploads/Schnell_JMP_042019.pdf.

Schnell, M., \& Currie, J. (2018). Addressing the opioid epidemic: is there a role for physician education? American Journal of
Health Economics, 4(3), 383-410. https://doi.org/10.1162 /ajhe_a_00113.

Schuchat, A., Houry, D., \& Guy, G. P. (2017). New data on opioid use and prescribing in the United States. JAMA, 318(5), 425426. https://doi.org/10.1001/jama.2017.8913.

Shover, C. L., Davis, C. S., Gordon, S. C., \& Humphreys, K. (2019). Association between medical cannabis laws and opioid overdose mortality has reversed over time. Proceedings of the National Academy of Sciences, 201903434. https://doi. org/10.1073/pnas.1903434116.

Small Business Administration. (2018). 2018 small business profile. In The US Small Business Administration Office of Advocacy Avaialable at: https://www.sba.gov/sites/ default/files/advocacy/2018-Small-Business-Profiles-US.pdf.

Song, Z. (2017). Mortality quadrupled among opioid-driven hospitalizations, notably within lower-income and disabled white populations. Health Affairs, 36(12), 2054-2061. https://doi.org/10.1377/hlthaff.2017.0689.

Swift, R. (2011). The relationship between health and GDP in OECD countries in the very long run. Health Economics, 20(3), 306-322. https://doi.org/10.1377/hlthaff.2017.0689.

University of Kentucky Center for Poverty Research (2017). UKCPR National Welfare Data, 1980-2016 (http://www. ukcpr.org/data) (accessed may 2018). In University of Kentucky, Gatton College of Business and Economics (Ed. ). Lexington, KY.

Vowles, K. E., McEntee, M. L., Julnes, P. S., Frohe, T., Ney, J. P., $\&$ van der Goes, D. N. (2015). Rates of opioid misuse, abuse, and addiction in chronic pain: a systematic review and data synthesis. Pain, 156(4), 569-576. https://doi.org/10.1097/01. j.pain.0000460357.01998.f1.

White House Council of Economic Advisors (2017). The underestimated cost of the opioid crisis. Executive Office of the President Washington, DC. Available at: https://www. whitehouse.gov/sites/whitehouse.gov/files/images/The $\% 20$ Underestimated $\% 20$ Cost $\% 20$ of $\% 20$ the $\% 20$ Opioid $\% 20$ Crisis.pdf

Publisher's note Springer Nature remains neutral with regard to jurisdictional claims in published maps and institutional affiliations. 